\title{
Emerging Challenge of Type 2 Diabetes: Prospects of Medicinal Plants
}

\author{
Rokeya Begum¹, Mosihuzzaman M², Azad Khan AK ${ }^{1,2}$, \\ Nilufar Nahar $^{3}$ and Ali Liaquat ${ }^{1,2}$ \\ ${ }^{1}$ Bangladesh Institute of Research and Rehabilitation in Diabetes, \\ Endocrine and Metabolic Disorder (BIRDEM); \\ ${ }^{2}$ Bangladesh Institute of health sciences (BIHS); \\ ${ }^{3}$ Dept of Chemistry, University of Dhaka \\ Bangladesh
}

\section{Introduction}

Diabetes mellitus, a complex metabolic disorder is an increasing concern, worldwide in terms of health. The disorder affects more than 100 million people worldwide and by 2030 it is predicted to affect 366 million. Type 2 diabetes, the commonest form of the disease globally, has now reached epidemic proportions in most parts of the world; rapidly developing countries are the forefront of this epidemic (WHO, 2006). This explosive increase in the prevalence of diabetes and the consequences of its complications and associated disorders represent the greatest health care challenge the world facing today.

It has been stated that, in the 'epidemics' of diabetes the developing world will suffer the most, with a predicted $170 \%$ increase in cases that will mainly affect the 45-64 years age group; by contrast, the diabetic population in developed countries will increase by only $40 \%$, and particularly among those aged $>65$ years (King et. al, 1998). Diabetes is an expensive disease, both to manage and because the associated morbidity and premature death impact so heavily on work and productivity; the massive increase among people of working age in the developing world will put a huge strain on the already overstretched health-care resources in these countries.

Type 2 diabetes is a complex disease. It is characterized by the combination of several interacting mechanisms like disturbances in insulin secretion, insulin action, glucose production and glucose uptake. Defect in one or more of these mechanisms due to either environmental and/or genetic factors, can lead to a dysregulated glucose homeostasis depicted by hyperglycemia, the cardinal finding of diabetes. The long-term consequences of hyperglycemia are severe including eye, heart, kidney and nerve damage. There is evidence that hyperglycemia is the primary cause of microvascular complications i.e retinopathy, neuropathy and nephropathy (ADA, 2003). Hyperglycemia also plays a vital role in the premature and accelerated development of macrovascular complications such as cardiovascular and peripheral vascular diseases. Incidence of coronary heart disease is much more common than in non-diabetic people, and up to $75 \%$ of patients die from cardiovascular causes. Life expectancy for middle-aged patients is shortened by 5-10 years, 
as compared with the general population (ADA, 2001; Katsilambros et al., 1991; Stamler et al., 1993).

Treatment of Type 2 diabetes is complicated by several factors inherent to the disease process. Diet and exercise play very important roles for diabetes management (Tuomilehto et al., 2001; Knowler et al., 2002). Oral hypoglycemic agents and/or insulin are being used to treat type 2 diabetes, all of which act through one of the pathways important in diabetes pathophysiology. However, even with these therapies diabetes remains an exceedingly difficult disease to control. No single agent has so far been unequivocally accepted to be 'the drug' in the management of diabetes. There is, therefore, an urgent need to develop new medications or strategies to counter the huge increase in cases expected in the future.

\section{Prospects of medicinal plants in the management of type $\mathbf{2}$ diabetes}

Plants have been used for the treatment of diabetes for centuries. However, their scientific evaluation has not constituted a substantial area of front-line pharmacological research in diabetes. A limited number of these plant species have been studied and validated for their hypoglycemic activities using diabetic animal models and in clinical studies using human subjects. Recently interest in plants has been increased particularly due to the relative lack of progress in the development of proper and save antidiabetic agents. Better understanding of the etipathogenesis of diabetic syndrome has paved the way for a more targeted use of plant materials in a modern pharmacological sense. In the perspective of the multiplicity of the pharmacological approaches against type 2 diabetes it is evident that plants provide interesting possibilities in these area because they contain thousands of compounds of which some may be useful as antidiabetic agents by themselves. Morever, the plant compound may form the basis for further manipulate to develop proper antidiabetic agents. Therefore, search for improved drug(s) against diabetes has remained a major goal among the biomedical researchers. Since approach of the scientists for synthesis of the conventional drugs has not yet brought expected results, many of them, in recent years, are focusing their attention on natural compounds to find, at least a lead if not a compound, of such antidiabetic agents.

\subsection{Management of Type 2 diabetes with traditional systems of medicine}

Traditional medicines are a fundamental aspect of basic health care needs globally. Over $64 \%$ of world's population (ca. 4.4 bn) use plants, in either crude or extract form as a primary health care source (Farnsworth, et al., 1985). A number of plants used as herbal drugs for diabetes therapy has been described in Ayurveda, Unani and other indigenous systems of medicine. Most of these traditional medicines are prepared from herbs, spices and plants, which do not form part of normal diet (Day \& Bailey, 1986; Bailey \& Day 1989). However, several common components of the diet are traditionally recommended for regular consumption, and some are additionally taken as infusions, decoctions or alcoholic extracts.

Plant materials have formed the basis for the treatment of diabetes in traditional medicines systems for thousands of years. These medicines for the treatment of diabetes mellitus are probably based mainly on treatment of its obvious symptoms. In ancient Ayurvedic medical texts such as the Charaka Samhita (Ca 2500 B.C.) and Sushruta Samhita (Ca 1000 B.C.) 
glycosuria was recognized as a symptom of diabetes (Nagarajan et al., 1982) whereas etiopathogenesis, clinical features and complications of diabetes have been described in another Ayurvedic medical text as Rogovinischaya (12 ${ }^{\text {th }}$ Century A.D). The Ayurvedic way of diabetes management include: advice for active life style, control over diet and different formulations for the treatment of diabetic complications. Sixty formulations of herbal and herbo-mineral origin under different categories like powder, paste, decoctions, etc. have been used in Ayurveda for diabetes management. Many mineral preparations (Bhasma) are also recommended.

\subsection{Plant materials and diabetes: Present scenario}

World's Ethnobotanical information about medicinal plants reports that almost 800 plants are used in the control of diabetes mellitus (Ajgaoonkar, 1979, Alarcon- Aguilara et al., 1998). More than 400 plants world-wide have been documented for the treatment of diabetes and majority await proper scientific and medical evaluation (Day \& Bailey, 1986). Over the last three decades, several comprehensive reviews (Oliver-Bever et al., 1979; Bailey, 1989; Ivorra et al., 1989; Subbulakshmi and Naik, 2001; Grover et al., 2002; Srinivasa, 2007) and extensive surveys (Marles \& Farnsworth, 1995; Simmonds \& Howes, 2006) have been published highlighting the fact that higher plants are of use in the treatment of diabetes, providing discussion on botany, phytochemistry, pharmacology and, in some cases, toxicology of the botanical agents. The extensive survey by Marles and Farnsworth (1995) reported that more than 1200 species of plants (in 725 genera and 183 families) are in use, and Simmonds and Howes (2006) mentioned that 656 plant species (in 437 genera and 11 families) have been used to treat diabetes and/or been investigated for antidiabetic activity. Recently a database of antidiabetic plants have been published (Singh et al., 2007) which contains information of medicinal plants having antihyperglycemic or antidiabetic activity. It includes 238 plants species and 123 Indian industries, which are using them.

There are very large and widely distributed families of antidiabetic plants, so the large number of species reported to have been used traditionally or experimentally for the treatment of diabetes may be coincidental. The most frequently cited families are Fabaceae, Asteraceae, Lamiaceae, Liliaceae, Poaceae and Euphorbiaceae (Marles \& Farnsworth, 1995). The phylogenetic distance between even this select group of families is a strong indication of the varied nature of the active constituents.

\subsection{Reported hypoglycemic plant compounds}

Cumulative research over the last few decades have already indicated some promising results that plants may serve as a source of antidiabetic compounds (Day, 1995). In many instances the chemical constituent(s) in the plant responsible for the biological activity has been isolated and identified, and some information is also available concerning the mechanism of action. A wide range of plant- derived principles belonging to different compounds have demonstrated bioactivity against hyperglycemia (Bailey \& Day, 1989; Ivorra et al., 1988; Ivorra et al., 1989; Bressler et al., 1969; Day, 1990; Marles \& Farnsworth, 1995). Hypoglycemic Natural Products of different classes are presented in Table 1.

The wide variety of chemical classes indicate that a variety of mechanisms must be involved in the lowering of the blood glucose levels. Some of these compounds may have therapeutic potential, while others may produce hypoglycemia, as side effects of their toxicity that is also another important concern. 


\begin{tabular}{|l|c|}
\hline Chemical class & Number active \\
\hline Alkaloids & 38 \\
\hline Carbohydrates & 66 \\
\hline Coumarins & 1 \\
\hline Cyanogenic glycosides & 1 \\
\hline Favonoids & 7 \\
\hline Glycopeptides & 20 \\
\hline Inorganic salts & 3 \\
\hline Iridoids & 4 \\
\hline Lipids & 6 \\
\hline Peptides and amines & 15 \\
\hline Phenolics (simple) & 4 \\
\hline Phenolpropanoid & 1 \\
\hline Steroids & 7 \\
\hline Stilbenes & 1 \\
\hline Sulfur compounds & 2 \\
\hline Terpenoids & 17 \\
\hline Vitamins & 2 \\
\hline Xanthenes & 2 \\
\hline
\end{tabular}

Table 1. Hypoglycemic Natural Products

\subsection{Research work on antidiabetic plant materials done by the Dhaka group}

Collaborative studies between the Biomedical Research group of BIRDEM and the Department of Chemistry, University of Dhaka, Bangladesh are conducted on antidiabetic plant materials following a standardized approach (Ali et al., 1993). Bangladesh and neighboring countries have a rich tradition in indigenous herbal medicine, therefore, in search of a new agent, considerable attention has been given on research with antidiabetic plant materials. Although screening of plant materials for hypoglycemic activities are abundantly found in literature, in-depth studies on the mechanism of action of these products are relatively lacking. In this design, a single plant material is tested in three models (nondiabetic, Type 1 and Type 2) of rats in three prandial states (fasting, simultaneously with oral glucose load, and $30 \mathrm{~min}$ before oral glucose load). Analysis of the results of these nine series of experiments helps not only to screen the hypoglycemic effects of the plant material, but also to postulate on their possible mechanism of action in target tissue(s). This, in turn, enables the investigator to conduct further in-depth studies on specific target tissue(s).

During the last twenty years 82 plants from Bangladesh, India, Pakistan, Nepal, Sri-lanka, China and Cameroon have been screened following the above approach. Some of them have shown promising results. From the results it was evident that screening of plant materials for hypoglycemic effects is not a straightforward task. The materials are active in particular model(s) and in particular prandial state(s) but may be inactive in other models and other prandial states. For example, bulb of a plant Stephania hernandifolia, used as antidiabetic remedy by the local people and traditional healers of Eastern Himalayan Belt, India, showed significant hyperglycemic activity in nondiabetic rats, no significant activity in Type 2 model 
rats and significant hypoglycemic activity in Type 1 model rats (Mosihuzzaman et al., 1994). The plants which showed promising results on screening, may be summarized into the groups as shown in Table 2 on the basis of their probable mechanism of action they have been classified into the following groups.

It is evident that, even the 9 series of experiments, as followed by us, are not fully exhaustive as other options are readily conceivable. Moreover, experiments have been done only after oral administration. A plant material may well be active when administered through other routes.

\begin{tabular}{|c|c|}
\hline Possible mechanism of action & Name of the plant material \\
\hline \multicolumn{2}{|l|}{ 1. Enhance or promote insulin secretion } \\
\hline Momordica charantia (Ali et al., 1993) & Costus speciosus (Mosihuzzaman et al., 1994) \\
\hline $\begin{array}{l}\text { Coccinia indica (Nahar et al., } 2000 \text { \& Rokeya et } \\
\text { al., 2003) }\end{array}$ & Premna integrifolia Linn (Alamgir et al., 2000) \\
\hline Spirulina platensis (Rokeya et al., 1999) & Bridelia ndellensis (Soheng et al., 2005) \\
\hline $\begin{array}{l}\text { Nephrolepsis tuberosa (Mosihuzzaman et al., } \\
\text { 1994) }\end{array}$ & Swetenia mahagoni (Rokeya et al., 2005) \\
\hline \multicolumn{2}{|l|}{ Pterospermum semisagittum (Khan et al., 2003) } \\
\hline \multicolumn{2}{|l|}{ 2. Inhibition of glucose absorption } \\
\hline $\begin{array}{l}\text { Trigonella foenum graceum (Ali et al., } 1995 \text { \& } \\
\text { Hannan et al., 2003) }\end{array}$ & Syzgium cumini (Rokeya et al., 1999) \\
\hline Plantago ovata (Rokeya et al., 1999) & Musa paradisiaca (Rokeya et al., 2000) \\
\hline Allium cepa (Rokeya et al., 1999) & Pterospermum acerifolium (Mamun et al., 2001) \\
\hline $\begin{array}{l}\text { Allium sativum (Rokeya et al., } 1999 \text { \& Retal et } \\
\text { al., } 1999 \text { \& 2000) }\end{array}$ & Costus Specious (Mosihuzzaman et al., 1994) \\
\hline Allium Wallicha & Spirulina platensis (Rokeya et al., 1999) \\
\hline Asparagus racemosus (Hannan et al., 2007) & Crateava Religiosa \\
\hline Ocimum sanctum (Alamgir et al., 2000) & Mangifera indica (Bhowmik et al., 2009) \\
\hline Ipomoea aquatica (Sokeng et al., 2007) & Tamarindus indicus \\
\hline \multicolumn{2}{|l|}{ 3. Action on the peripheral tissues } \\
\hline Coccinia indica (Nahar et al., 2000) & $\begin{array}{l}\text { Nephrolepsis tuberosa (Mosihuzzaman et al., } \\
\text { 1994) }\end{array}$ \\
\hline \multicolumn{2}{|l|}{ Costus speciosus (Mosihuzzaman et al., 1994) } \\
\hline \multicolumn{2}{|l|}{ 4. Mixed activity } \\
\hline Hemidesmus indicus (Murshed et al., 2005) & Gymnema sylvestre (Rokeya et al., 2000) \\
\hline $\begin{array}{l}\text { Caesalpinia bonducella (Chakrabarti et al., } \\
\text { 2003) }\end{array}$ & Ocimum sanctum (Alamgir et al., 2001) \\
\hline \multicolumn{2}{|l|}{ Allium sativum (Rokeya et al., 2000) } \\
\hline \multicolumn{2}{|c|}{ 5. Prevention of islet damage or possibility of $\beta$-cell regeneration } \\
\hline Gymnema sylvestre (Rokeya et al., 1999) & $\begin{array}{l}\text { Stephania hernandifolia (Mosihuzzaman et al., } \\
\text { 1994) }\end{array}$ \\
\hline \multicolumn{2}{|l|}{ 6. $\quad$ Improving insulin sensitivity } \\
\hline Gymnema sylvestre (Ali et al., 2005) & \\
\hline
\end{tabular}

Table 2. Anidiabetic plant materials reported by the Dhaka Group 


\subsubsection{Studies on the antidiabetic effect and mechanism of action of Nyctanthes Arbortristis Linn.}

This is one example of screening methodology followed by mechanistic study. Nyctanthes arbortristis Linn (Seoli) is a shrub (a C 3 plant; Rao \& Kodandaramaiah, 1982) cultivated as a garden plant throughout Bangladesh and in the Sub-Himalayan region. In Ayurvedic and Unani medicine the leaves of this plant is used extensively for the treatment of various ailments (Singh et al., 1995; Chopra et al., 1956; Srivastava et al., 1990). In Ayurvedic system of medicine the seeds are being used for throat and eye diseases, skin infections, intestinal worm infection, leprosy, etc (RB Singh \& Jindal, 1985). To the best of our knowledge there is no published report on the antidiabetic properties of this plant. As a routine screening programme this plant has been undertaken for studying the effect on serum glucose level of nondiabetic and diabetic rat models. Ripe seeds and fresh leaves of $N$ arbortristis were collected from Dhaka, Bangladesh. The plant was identified at Bangladesh National Herbarium and a voucher specimen (DACB-35121) was deposited.

\subsubsection{Materials \& methods}

Aquous extract of seed and $2 \%$ ethanol extract of leaf were used for the study at a dose of $1.25 \mathrm{~g} / \mathrm{kg}$ bw. Male Long-Evans rats bred at BIRDEM Animal House, weighing between 180-200 gm were used to carry out the experiment. All the experiments were carried out following the International Guidelines for handling of laboratory Animals (Derrell, 1966). Type 1 and Type 2 diabetes were produced with intraperitoneal injection of Streptozotocin using conventional methods and following the procedure standardized in BIRDEM. Acute experiments were done in normal, Type 1 and Type 2 diabetic model rats at different prandial states. Blood samples were collected by cutting the tail tip under mild ether anesthesia. The glucose levels in the serum samples in duplicate were estimated by GODPAP method (Boehringer Mannheim GMBH). Statistical analyses were performed by using one- way ANOVA.

\subsubsection{Results}

Screening result for hypoglycemic activity of aqueous extract of seed and $2 \%$ ethanol extract of leaf in nondiabetic rats showed no effect in the fasting or postprandial state when fed simultaneously with glucose load. Ethanol extract of arbortristis seed significantly $(\mathrm{p}<0.05)$ opposed the rise of serum glucose at $60 \mathrm{~min}$ when the extract was fed 30 minutes before glucose load in nondiabetic rats (data not shown).

Aquous seed and leaf extract did not show any hypoglycemic activity in Type 1 rats in fasting and 30 minutes before the glucose load state (Table 3). When administered simultaneously with glucose, leaf extract showed significant anti-hyperglycemic effect at $75 \mathrm{~min}(\mathrm{p}<0.05)$.

Nyctanthes arbortristis seed extract significantly lowered fasting blood glucose levels in Type 2 diabetic rats at $120 \mathrm{~min}(\mathrm{p}<0.05)$ and also showed significant anti-hyperglycemic effect at $75 \mathrm{~min}(\mathrm{p}<0.01)$ when fed simultaneously with glucose (Table 4$)$.

Aquous extract of seed was effective in lowering serum glucose level of nondiabetic rats only in postprandial states when fed $30 \mathrm{~min}$ before glucose load indicating more of a systemic action. These also include the possibility of inhibition of gastric emptying (Lembcke, 1987) and also the involvement of gut hormones (Creutzfeld, 1979). Seed extract also showed significant effect in Type 2 rats at the fasting and in postprandial states when fed simultaneously with glucose load. This extract might contain some hypoglycemic 


\begin{tabular}{|c|c|c|c|}
\hline Group & \multicolumn{3}{|c|}{ Serum glucose level mmol/l } \\
\hline Fasting & $0 \mathrm{~min}$ & $60 \mathrm{~min}$ & $120 \mathrm{~min}$ \\
\hline Water control $(n=6)$ & $22.10 \pm 2.91$ & $22.02 \pm 2.53$ & $20.29 \pm 1.33$ \\
\hline Insulin control $\quad(n=6)$ & $20.33 \pm 0.99$ & $3.60 \pm .57^{* * *}$ & $2.35 \pm 0.12^{* * *}$ \\
\hline$N$ arbortristis ripe seed $(\mathrm{n}=7)$ & $22.72 \pm 2.53$ & $22.37 \pm 2.74$ & $21.11 \pm 2.49$ \\
\hline$N$ arbortristis leaf $\quad(\mathrm{n}=7)$ & $21.87 \pm 2.20$ & $20.92 \pm 2.26$ & $22.29 \pm 3.02$ \\
\hline $\begin{array}{l}\text { Simultaneously with glucose } \\
\text { load }\end{array}$ & $0 \mathrm{~min}$ & $30 \mathrm{~min}$ & $75 \mathrm{~min}$ \\
\hline Water control $(n=6)$ & $22.25 \pm 1.86$ & $34.19 \pm 1.31$ & $32.03 \pm 0.75$ \\
\hline Insulin control $(n=6)$ & $22.52 \pm 0.47$ & $22.10 \pm 0.66^{* * *}$ & $11.40 \pm 1.15^{* * *}$ \\
\hline$N$ arbortristis ripe seed $(\mathrm{n}=10)$ & $24.45 \pm 1.20$ & $32.50 \pm 1.16$ & $27.11 \pm 2.30$ \\
\hline$N$ arbortristis leaf $(\mathrm{n}=8)$ & $22.33 \pm 0.82$ & $30.56 \pm 1.08$ & $25.91 \pm 2.79^{*}$ \\
\hline $30 \mathrm{~min}$ before glucose load & $0 \mathrm{~min}$ & $60 \mathrm{~min}$ & $105 \mathrm{~min}$ \\
\hline Water control $(\mathrm{n}=5)$ & $22.16 \pm 4.64$ & $30.35 \pm 3.34$ & $26.65 \pm 2.82$ \\
\hline Insulin control $(n=6)$ & $21.38 \pm 3.18$ & $9.47 \pm 4.12^{* * *}$ & $5.21 \pm 1.97 * * *$ \\
\hline N. arbortristis ripe seed $(n=7)$ & $19.63 \pm 3.25$ & $27.68 \pm 2.98$ & $24.35 \pm 2.77$ \\
\hline$N$ arbortristis leaf $(\mathrm{n}=6)$ & $19.47 \pm 6.07$ & $27.32 \pm 3.82$ & $27.21 \pm 4.03$ \\
\hline
\end{tabular}

Values are mean $\pm \mathrm{SE} ; \mathrm{n}=$ number of rats; ${ }^{*} \mathrm{p}<0.05,{ }^{* *} \mathrm{p}<0.01,{ }^{* * *} \mathrm{p}<0.001$ compared to control rat.

Table 3. Effect of aqueous extract of Nyctanthes arbortristis seeds and $2 \%$ ethanol extract of leaves on serum glucose levels of Type 1 diabetic models rats in different prandial states.

\begin{tabular}{|c|c|c|c|}
\hline Group & \multicolumn{3}{|c|}{ Serum glucose level mmol/l } \\
\hline Fasting & $0 \mathrm{~min}$ & $60 \mathrm{~min}$ & $120 \mathrm{~min}$ \\
\hline Water control $(n=6)$ & $8.48 \pm 0.47$ & $8.36 \pm 0.33$ & $7.85 \pm 0.22$ \\
\hline Glibenclamide control $(n=6)$ & $8.36 \pm 0.25$ & $7.25 \pm 0.32^{*}$ & $6.750 \pm 0.24$ ** \\
\hline$N$ arbortristis seed $(\mathrm{n}=7)$ & $7.21 \pm 0.18$ & $8.83 \pm 0.10$ & $6.99 \pm 0.14^{*}$ \\
\hline$N$ arbortristis leaf $(\mathrm{n}=7)$ & $6.90 \pm 0.24$ & $7.77 \pm 0.08$ & $7.49 \pm 0.13$ \\
\hline Simultaneously with glucose load & $0 \mathrm{~min}$ & $30 \mathrm{~min}$ & $75 \mathrm{~min}$ \\
\hline Water control $(n=6)$ & $8.08 \pm 0.99$ & $17.06 \pm 0.49$ & $15.89 \pm 0.54$ \\
\hline Glibenclamide control $(n=6)$ & $8.28 \pm 0.78$ & $19.19 \pm 1.42$ & $16.97 \pm 1.16$ \\
\hline$N$ arbortristis seed $(\mathrm{n}=8)$ & $8.32 \pm 0.92$ & $15.43 \pm 1.09$ & $9.01 \pm 0.05^{\star *}$ \\
\hline$N$ arbortristis leaf $(\mathrm{n}=7)$ & $7.12 \pm 0.85$ & $15.42 \pm 1.39$ & $16.22 \pm 0.96$ \\
\hline $30 \mathrm{~min}$ before glucose load & $0 \mathrm{~min}$ & $60 \mathrm{~min}$ & $105 \mathrm{~min}$ \\
\hline Water control $(n=6)$ & $9.21 \pm 0.50$ & $18.57 \pm 1.61$ & $17.63 \pm 0.95$ \\
\hline Glibenclamide control $(\mathrm{n}=7)$ & $8.99 \pm 0.47$ & $16.78 \pm 1.94$ & $15.03 \pm 1.68$ \\
\hline$N$ arbortristis seed $(\mathrm{n}=5)$ & $9.43 \pm 0.28$ & $19.50 \pm 1.79$ & $19.01 \pm 1.74$ \\
\hline$N$ arbortristis leaf $(\mathrm{n}=6)$ & $9.76 \pm 0.81$ & $17.64 \pm 1.74$ & $19.36 \pm 1.62$ \\
\hline
\end{tabular}

Values are mean $\pm S E ; n=$ number of rats; ${ }^{*} \mathrm{p}<0.05,{ }^{* *} \mathrm{p}<0.01,{ }^{* * *} \mathrm{p}<0.001$ compared to control rat.

Table 4. Effect of aqueous extract of Nyctanthes arbortristis seeds and $2 \%$ ethanol extract of leaves on fasting serum glucose levels of Type 2 diabetic models rats in different prandial states. 
principles, which act probably by stimulation of insulin secretion from $\beta$-cells of islets or acting either at the gut level or at the peripheral tissues. Analysis of the nature of the action of the $2 \%$ ethanol extract of leaf in Type 1 model (no effect in fasting state and $30 \mathrm{~min}$ before glucose load, but significant effect when fed simultaneously with glucose load) indicates its probable effect at the glycogen synthesis level, since glycogenesis (enhanced by feeding) is the predominant mechanism at fed state in contrast to the gluconeogenesis which is characteristically activated at fasting state in diabetic animals (Felig \& Bergman, 1990).

The results of the oral acute hypoglycemic effects on normal and Type 2 diabetic rats at fasting and postprandial conditions suggested that blood glucose lowering effect of the seed extract of $N$ arbortristis is probably due to enhanced insulin-releasing activity.

\subsubsection{Studies on the mechanism of insulin secretion}

The effect of the ethanol (PE080) and chloroform (PE081) extracts of seed were also evaluated on insulin secretion together with exploration of their mechanism of action together with exploration of their mechanism of action in isolated perfused rat pancreas and BRIN-BD11 insulin secreting cell (Rokeya et al., 2006).

Experimental procedure: To study the effects of the extracts on insulin secretion Long-Evans rats were anesthetized with sodium pentobarbital solution and the pancreas was isolated and perfused through mesenteric and celiac vessels of whole pancreas at $37^{\circ} \mathrm{C}$ according to the Method of Giroix et al. (1983). Both the extracts were dissolved at a dose of $0.1 \mathrm{mg} / \mathrm{ml}$ in Krebs-Ringer bicarbonate buffer containing $2.8 \mathrm{mM}$ or $11.1 \mathrm{mM}$ D glucose. The perfusate was continuously gassed with a mixture of O2:CO (95:50). After 20 min equilibration period the composition of the perfusate was changed every ten min with plant extracts and other reagents. The effluent was collected at 1 minute interval from the portal vein. Effluent samples were frozen and stored at $-20^{\circ} \mathrm{C}$ for insulin assay.

Clonal BRIN-BD11 cells (McClenaghan et al., 1996) were also used to evaluate the action of ethanol and chloroform extracts on insulin secretion. Cell viability was evaluated by modified neutral assay (this part of wrk was done in the Diabetes Research Group, University of Ulster, UK).

For perfusion studies and studies with BRIN-BD11 cells insulin was measured by ELISA and by radioimmunoassay respectively. Results are presented as mean $\pm S D$ for a given number of observations(n). Data from each set of observations were compared using unpaired Student's t-test and Mann-Whitney U test where appropriate (SPSS for Windows). One-way ANOVA was performed and comparisons to the control group was made using Dunnet's test to preserve overall error rate of $5 \%$. Differences were considered significant if $\mathrm{p}<0.05$.

\section{Results}

Fig. 1 shows that PE080 stimulated insulin secretion in isolated perfused rat pancreas which caused a significant increase in insulin release during 10 minute perfusion with almost a 6fold increase above basal level (Insulin, $\mathrm{M} \pm \mathrm{SD} \mathrm{ng} / \mathrm{ml}$; $0.204 \pm 0.02$ basal vs $1.22 \pm 0.12$ PE080, Peak value; $\mathrm{p}<0.001)$. PE081 did not evoke a significant increase on insulin secretion.

It is establised that studies using insulinotropic antagonists can define the possible mechanism of action in enhancing insulin secretion and confirm absence of insulin leakage by more lysis of cells. Therefore, in our experiment one such inhibitor utilized was diazoxide, an ATP-sensitive $\mathrm{K}+$ chanel opener. Fig 2 shows that diazoxide $(300 \mu \mathrm{M})$ inhibited the insulin enhancing effects of PE080 in the perfused panceaes (Insulin M $\pm S D, n g / m l ;$ 
1.22 \pm 0.12 PE080 vs $0.42 \pm 0.05$ PE080 + diazoxide; $\mathrm{p}<0.01$ ) indicating the involvement of the extract in the stimulus-secretion coupling pathway at the closure of $\mathrm{K}+$-ATP channels (Henquin, 1992).

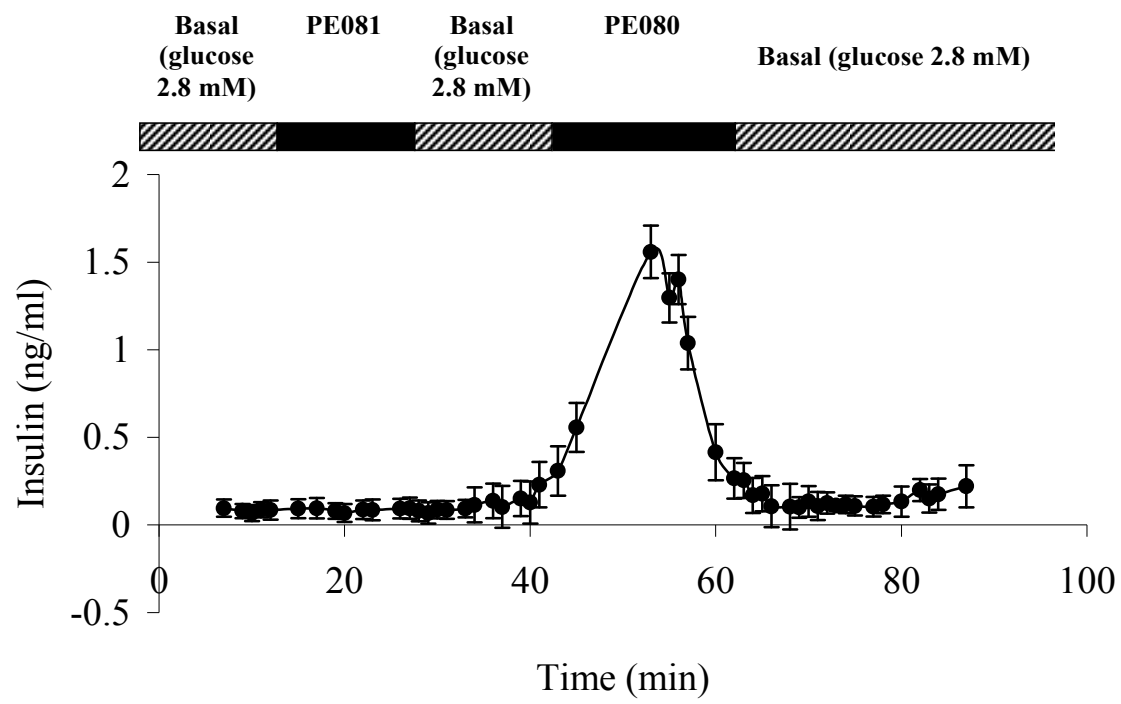

Fig. 1. Effects of PE081 and PE080 on insulin secretion from perfused rat pancreas in basal state. Insulin released in presence of PE080

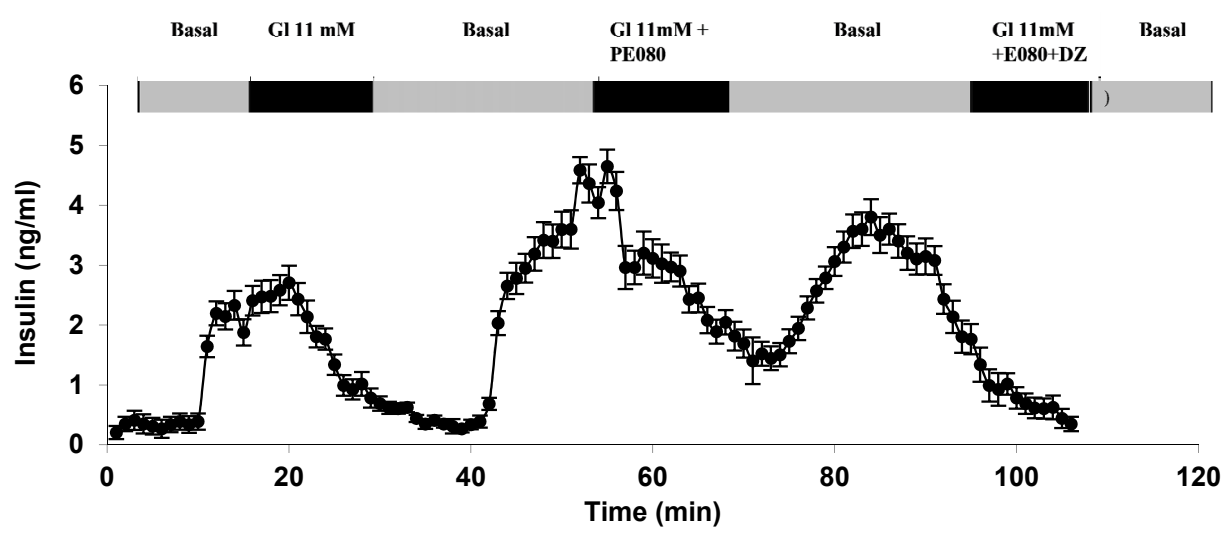

Fig. 2. Insulin release in glucose stimulated state and in presence of diazoxide.

The insulinotropic effects and cellular detrimental effects of PE080 and PE081 with two concentrations of each $(50 \mathrm{g \mu} / \mathrm{ml}$ and $100 \mu \mathrm{g} / \mathrm{ml})$ were evaluated in BRIN-BD11 cell line. It was found that, in this cell line (Table 5) PE080 stimulated insulin release in both the concentrations (50 and $100 \mu \mathrm{g} / \mathrm{ml}$ ) compared to control (5.6 mM glucose). The Table 5 shows that the higher concentration did not affect cell viability. PE081 in $100 \mu \mathrm{g} / \mathrm{ml}$ 
concentration stimulated insulin release which was also not associated with a significant reduction in cell viability.

These findings revealed that PE080 and PE081 exert stimulatory effects on insulin secretion from the $\beta$-cells mediated through a physiological insulinotropic pathway. In vivo studies also indicate that aquous extract of Nyctanthes arbortristis seeds decreased serum glucose in Type 2 diabetic model rats. The identification of active principle(s) from seeds of Nyctanthes arbortristis PE080 and PE081 may provide interesting possibilities against diabetes.

\begin{tabular}{|l|l|l|}
\hline Group & Cell viability (\%) & Insulin (ng/ml) \\
\hline $5.6 \mathrm{mM}$ glucose & $98.58 \pm 5.19$ & $1.45 \pm 0.087$ \\
\hline PE081 $(50 \mu \mathrm{g} / \mathrm{ml})$ & $96.70 \pm 4.81$ & $1.46 \pm 0.23$ \\
\hline PE081 $(100 \mu \mathrm{g} / \mathrm{ml}$ & $92.02 \pm 3.87^{* *}$ & $2.29 \pm 0.41^{* * *}$ \\
\hline PE080 $(50 \mu \mathrm{g} / \mathrm{ml})$ & $96.39 \pm 4.07$ & $2.26 \pm 0.25^{* * *}$ \\
\hline PE080 $(100 \mu \mathrm{g} / \mathrm{ml})$ & $93.30 \pm 5.15$ & $3.36 \pm 0.60^{* *}$ \\
\hline$t / p$ value & \multicolumn{2}{|l|}{} \\
\hline $5.6 \mathrm{mM} \mathrm{gl} \mathrm{vs} \mathrm{PE081}(50 \mu \mathrm{g} / \mathrm{ml})$ & $0.75 / 0.465$ & $0.032 / 0.975$ \\
\hline $5.6 \mathrm{mM} \mathrm{gl} \mathrm{vs} \mathrm{PE081}(100 \mu \mathrm{g} / \mathrm{ml})$ & $2.86 / 0.012$ & $7.044 / 0.001$ \\
\hline $5.6 \mathrm{mM} \mathrm{gl} \mathrm{vs} \mathrm{PE080}(50 \mu \mathrm{g} / \mathrm{ml})$ & $0.94 / 0.364$ & $10.39 / 0.001$ \\
\hline $5.6 \mathrm{mM} \mathrm{gl} \mathrm{vs} \mathrm{PE080}(100 \mu \mathrm{g} / \mathrm{ml})$ & $2.041 / 0.061$ & $10.87 / 0.001$ \\
\hline
\end{tabular}

Table 5. Effects of different concentrations of PE081 and PE080 of on BRIN-BD11 cell viability and insulin secretion.

\subsubsection{Studies on the retardation of glucose absorption in the gut}

The retardation of carbohydrate digestion and absorption in the gut is now a potential therapeutic approach for the management of diabetes mellitus. The intestinal disaccharidase enzymes (a-glucosidase) are involved in the digestion and absorption of carbohydrate and inhibition of these enzymes by the agents may slow this process and thus leads to a slower and less pronounced rise in postprandial blood glucose levels. It has been confirmed that some plant fractions i.e hot water extract extract of $T$ foenumgraecum $P$. ovata and ethanol extracts of $O$ sanctum, A racemosus, $M$ indica (Bhowmik 2009), $T$ indica (not published) significantly inhibited the absorption of glucose during perfusion of gut with glucose solution, a mechanism postulated before through in vivo experiments. $T$ foenumgraecum (Hannan, et.al., 2003 \& 2007a) , P. ovata (Hannan, et.al., 2006a) O sanctum (Hannan, et.al., 2006b) and $A$ racemosus, (Hannan, et.al., 2007b) increased unabsorbed sucrose content throughout gut when administered with sucrose and also inhibitited intestinal disaccharidase enzyme activity, which reveals that the retardation of carbohydrate absorption is related to the inhibition of gut enzyme activity. However, they did not increase GI tract motility (by Barium meal studies) which suggests that inhibition of glucose absorption is not related to enhance peristaltic movement of gut.

\subsubsection{Discussion}

It is utmost important to compile information regarding the toxicity of all medicinal plants as plant extracts may exert different types of toxicities like hepatic, renal, cardiac, hematological and other toxicities through their inherent properties. Therefore, antidiabetic plants which show hypo-/antihyperglycemic properties in animal models or 
in humans should be tested for their possible toxicities. If found to have some degree of toxicity, the risks can be weighed against the benefits and decisions can be made regarding their continued availability. The plant materials which have been mentioned here, a few of them were studied with a longer durationin in streptozotocin induced diabetic model rats (Chakrabarti et al 2005; Bandara et al 2010) and also inType 2 diabetic subjects (Bandara et al 2019). After chronic oral feeding their serum alanine amino transferase (ALT) and serum creatinine levels have been determined as a marker of liver and kidney toxicities. Chronic consumption of these plant materials did not indicate any adverse effect on liver and kidney functions of Type 2 rats or Type 2 patients as serum ALT and creatinine levels remained unchanged throughout study period. It should be kept in mind that the inherent properties of the plants are not the sole source of plant related hepatic, renal, cardiac, hematological or other disorders. There may be some other factors like i) plant material and drug interactions, ii)mistakes in dosage and identification and iii) presence of adulterants etc. All these issues of concern should be taken into account to eliminate toxicity and ensure the safety of not only the antidiabetic but all medicinal plant products.

\subsubsection{Practical guidelines regarding usefulness}

To study the traditionally used plant materials is not only a scientific but also a social responsibility. Whether liked or not a large number of people, particularly in the developing countries, are still dependent on plants. It is important to screen their efficacy and it may also be helpful if the best timing, dose and the method of administration of these materials can be suggested. It is also important to warn people against injudicious dependence on plants for the management of diabetes. Although, the modern treatment for diabetes has not reached perfection, it has become possible to control the disorder and lead a normal and productive life. So, a clinician must be aware that the well-being of the patient is not scarified merely due to a psychological preference to use plant materials. If diabetes of a patient is not under control after using plant materials, the clinician should not hesitate to use the modern drugs against diabetes.

\section{Conclusions}

Prevalence of diabetes mellitus is increasing and it causes substantial morbidity and mortality through macro- and microvascular complication, especially in developing countries where adequate treatment is often unavailable. Since almost $90 \%$ of the people in rural areas of developing countries still rely on traditional medicines for their primary health care and scientific investigations of traditional medicines have led to the discovery of 122 compounds obtained from only 94 species of plants which are used as drugs worldwide (Fabricant \& Farnsworth, 2001) therefore, the development of new antidiabetic drug(s) from traditionally used plants seems to be probable. From the existing evidence it appears that plants have got a vast potential to provide source materials for antidiabetic agents. However, this potential has remained largely unexplored. A rationally designed interdisciplinary research program i.e. involvement of scientists from diverse disciplines of biomedical sciences, may also lead to the development of scientifically tested indigenous, remedies for diabetes through sustainable and cost-effective use of medicinal plant resources. 


\section{Acknowledgments}

We gratefully acknowledge the active advice and support of the Department of Medical Cell Biology, Uppsala Univesity, Sweden (group led by Prof Bo Hellman and Prof Erik Gylfe) and the Dept of Chemistry, Mahidol University, Bangkok (group led by Prof Vichai Reutrakul) during these studies. We also express our sincere thanks to International Program in the Chemical Sciences (IPICS), Uppsala University, Sweden, International Foundation for Sciences (IFS), Stockholm, Sweden, Asian Netwirk of research on antidiabetic plant materials (ANRAP) Dhaka, Bangladesh, Diabetic Association of Bangladesh, Ministry of Science and Information and Communication Technology, Bangladesh, University Grant Commission and Dhaka University, Bangladesh for their financial and logistic support in all our studies.

\section{References}

Ajgaonkar, S.S. (1979). Herbal drugs in the treatment of diabetes. Int Diabetes Fed Bull, Vol. 24, pp. 10-17.

Alamgir, M.; Rokeya, B.; Chowdhury, N.S. and Choudhury, M.S.K (2001). Antihyperglycemic effect of aqueous extract of Ocimum sanctum Linn (Labiateae) in type 2 diabetic model rats. Diab Res, Vol.36, pp. 019-027

Alamgir, M.; Rokeya, B.; Hannan, J.M.A. \& Choudhuri, M.S.K. (2001). The effect of Premna integrifolia Linn. (Verbenaceae) on blood glucose in streptozotocin induced type 1 and type 2 diabetc rats. Pharmazie, Vol. 56, pp. 903-904.

Alarcon-Aguilara, F.J.; Roman-Ramos, R.; Perez-Gutierrez, S.; Aguliar-Contreras, A.; Contreras-Weber, C.C. \& Flores-Saenz, J.L. (1998). Study of the hypoglycemic effect of plants used as antidiabetics, F Ethnopharmacol, Vol. 61. pp.101-110.

Ali, L.; Azad Khan, A.K.; Hassan, Z.; Mosihuzzaman, M.; Nahar, N.; Nasreen, T.; Nur-eAlam, M.; Parveen, M.; Rokeya, B. (1995). Characterization of the hypoglycemic effects of Trigonella foenum graecum seed extracts on normal and diabetic model rats. Planta Medica, Vol. 61, pp. 358-360.

Ali, L.; Chowdhury, N.; Rokeya, B.; Chaudhury, H.S.; Hannan, J.M.A.; Khaleque, J.; Akhter, M.; Hassan, Q.; Murshed, S.; Nahar, N.; Azad Khan, A.K.; Mosihuzzaman, M. (2005). Antidiabetic effects of plant extract PE052 on type 1 diabetic model rats. Diabetologia;Suppl 1 pp. 763: A

American Diabetes Association. (2003). Standards of medical care for patients with diabetes mellitus. Diabetes care, Vol. 26, No. 1, pp. S33-S50.

American Diabetes Association. Mortality. (2001). In: American Diabetes Association, eds. Diabetes Vital Statistics. Alexandria, VA: American Diabetes Association; pp. 77-85.

Bandara, T.; Rokeya, B.; Khan, S.; Ali, L.; Ekanayake, S.; Balasubramanium, K. (2009). Effects of Gymnema lactiferum leaves on, glycemic and lipidemic status in type 2 diabetes subjects. Bangladesh J Pharmacol, Vol. 4, pp.92-98.

Bandara, T.; Rokeya, B.; Ekanayake, S.; Ali, L.; Raddy, E.; Balasubramanium, K. (2010). Effects of Gymnema lactiferum leaf on serum glucose and cholesterol levels of Streptozotocin induced diabetic rats. Int J Boil Chem Sci, Vol. 9, pp.815-819.

Bailey, C.J. \& Day, C. (1989). Traditional plant medicines as treatments for diabetes. Diabetes Care, Vol.12, pp.553-64. 
Bhowmik, A., Liakot, A. K.; Akhter, M. \& Rokeya, B. (2009). Study on Antidiabetes effects of mango (Mangifera indica) stem-barks and leaves on Nondiabetic and Diabetic model rats. Bangladesh J Pharmacol (BDPS), Vol. 4, No. 2, pp. 110-114.

Bressler, R.; Correndor, C. \& Brendel, K. (1969). Hypoglycin and hypoglycin-like compounds. Pharmacol Revs, Vol. 21, pp.105-30.

Chakrabarti, S.; Biswas, T.K.; Rokeya, B.; Ali, L.; Mosihuzzaman, M.; Nahar, N.; Azad Khan, A.K. \& Mukherjee, B.P. (2003) Advanced studies on the hypoglycemic effect of Caesalpinia bonducella F. in type I and II diabetes in Long Evans rats. $J$ of Ethnopharmacology, Vol. 84, pp. 41-46.

Chakrabarti S., Biswas T. K., Seal T., Rokeya B., Ali L., Azad Khan AK, Nahar N. , Mosihuzzaman M. and Mukherjee B.: Antidiabetic activity of Caesalpinia bonducella F. in chronic type 2 diabetic model in Long Evans rats and evaluation of insulin secretagogue property of its fractions on isolated islets. J Ethnopharmacology 2005, 97: p-117-122.

Chopra, R.N.; Nayar, S.L. \& Chopra, I.C. (1956). Glossary of Indian Medicinal Plants. CSIR, New Delhi, pp. 177.

Creutzfeld, W. (1979). The incretion concept today. Diabetologia, Vol.16, pp.75-85.

Day, C. (1995). Hypoglycemic plant compounds Pract. Diabetes, Vol. 12, pp. 245-96.

Day, C.; \& Bailey, C.J. (1986). Hypoglycemic agents from traditional plant treatments for diabetes. Int Indus Biotechnol, Vol. 8, pp. 5-8.

Derrell, C. (1996). Guide for the care and use of laboratory animals. Istitute of Laboratory Animal Resources. National Academy Press, Washington DC, USA.

Fabricant, D.S. \& Farnsworth, N. (2001). R.The Value of Plants Used in Traditional Medicine for Drug DiscoveryEnviron Health Perspect 109(suppl 1):69 - 75.

Famsworth, N. R.; Akerele, O.; Bingel, A. S.; Soejarto, D. D. \& Guo, Z.G.(1985). Medicinal plants in therapy. Bull. WHO, Vol. 63, pp. 965-981.

Felig, P. \& Bergman, M. (1990). In Diabetes Mellitus: Theory and Practice. 2nd Edition (ed. H.Rifkin and D. Jr. Portc), pp. 51-60.

Giroix, M.H.; Portha, B.; Kergoat, M.; Bailbe, D. \& Picon, L. (1983). Glucose insensitivity and amino-acid hypersensitivity of insulin release in rats with non-insulin-dependent diabetes: a study with the perfused pancreas. Diabetes. Vol. 32, pp. 445-51.

Grover,J.K.; Yadav, S.; \& Vats, V. (2002). Medicinal plants of India with anti-diabetic potential. J Ethnopharmacol, Vol. 81, pp. 81-100.

Hannan, J.M.A.; Ali, L.; Rokeya, B.; Khaleque, J.; Akhter, M.; Flatt, P.R. \& Abdel-Wahab, Y.H (2007a). Soluble dietary fibre fraction of Trigonella foenum-graecum (fenugreek) seed improves glucose homeostasis in animal models of type 1 and type 2 diabetes by delaying carbohydrate digestion and absorption, and enhancing insulin action. Br J Nutr, Vol. 97, No. 3, pp. 514-21.

Hannan, J.M.A.; Marenah, L.; Ali, L.; Rokeya, B.; Flatt PR \& Wahab YHA (2007b): Insulin secretory actions of extracts of Asparagus racemosus root in perfused pancreas, isolated islets and clonal pancreatic beta-cells. J Endocrinology; 192: 159-68.

Hannan, J.M.A.; Marenah, L.; Ali, L.; Rokeya, B.; Flatt, P.R. \& Wahab, Y.H.A (2006). Ocimum sanctum leaf extracts stimulated insulin secretion from perfused pancreas, isolated islets and clonal pancreatic beta-cells. J Endocrinology, 189 (No 1): 127-136.

Hannan, J.M.A.; Rokeya, B.; Faruque, O.; Nahar, N.; Mosihuzzaman, M. \& Ali, L. (2003). Effect of Soluble Dietary Fibre fraction of Trigonella foenum-graecum on glycemic, 
insulinemic, lipidemic and platelet aggregation status of Type 2 diabetic model rats. J Ethnopharmacology, Vol. 88, pp. 73-77.

Henquin, J.C.; Debuyser, A.; Drews, G. \& Plant, T.D. (1992). Regulation of K+ permeability and membrane potential in insulin-secretory cells. In: Flatt PP (ed) Nutrient regulation of insulin secretion. Porland, London, pp. 173-192.

Ivorra, M.D., D, Ocon, M.P.; Paya, M. \& Villar, A. (1988). Anti hyperglycemic and insulin releasing effects of $\beta$-sitosterol-3-b-Dglucoside and its aglycon, $\beta$-sitosterol. Arch Int Pharmaodyn Therap, Vol. 296, pp. 224-31.

Ivorra, M.D.; Paya, M.; Villar, A. (1989). A review of natural products and plants as potential antidiabetic drugs , J Ethnopharmacol, Vol. 27, pp. 243-75.

Katsilambros, N.; Hatzakis, A.; Perdicaris, G.; Pefanis, A. \& Touloumi, G. (1991). Total and cause-specific mortality in a population based cohort in Greece. Diabetes Metab, Vol. 17, pp. $410-14$.

Khan, S.H.; Mosihuzzaman, M.; Nahar, N.; Rashid, M.A.; Rokeya, B.; Ali, L. \& Azad Khan, A.K. (2003). Three Megastigmane Glycosides from the leaves of Perospermum semisagittatum. Pharmaceutical Biology, Vol. 41, pp. 512-515.

King, H.; Aubert, R.E. \& Herman, W.H. (1998). Global burden of diabetes, 1995-2025: prevalence, numerical estimates, and projections. Diabetes Care, Vol. 21, pp. 141431.

King, H.; Aubert, R.E. \& Herman, W.H. (1998). Global burden of diabetes, 1995-2025: prevalence, numerical estimates and projections. Diabetes Care, Vol. 21, pp. 1414-31.

Knowler, W.C.; Barrett-Connor, E. Fowler, S.E.; Hamman, R.F.; Lachin, J.M.; Walker, E.A. \& Nathan, D.M. (2002). Reduction in the incidence of type 2 diabetes with lifestyle intervention or metformin. N. Engl. J. Med, Vol. 346, pp. 393-403. [PMC free article] [PubMed]

Lembcke, B. (1987). Control of absorption: delaying absorption as a therapeutic principle. In: Structure and Function of the Small Intestine (edited by W. F. cospary). Excerpta Medica, Amsterdam, pp. 263-280.

Mamun, M.I.R.; Rokeya, B.; Chowdhury, N.S.; Muniruzzaman, M.; Nahar, N.; Ahmed, M.U.; Mosihuzzaman, M.; Ali, L., Azad Khan, A.K. \& Khan, S.H. (2001). Antihyperglycemic effect of Pterospermum acerifolium Willd. And Pterospermum semisagittatum Ham. Diab Res, Vol. 35, pp.163-170.

Marles, R.J. \& Farnsworth, N.R. (1995). Antidiabetic plants and their active constituents. Phytomedicine, Vol. 2, No. 2, pp. 137-189.

McClenaghan, N.H.; Barnett, C.R.; Ah-Sing, E.; Abdel-Wahab, Y.H.A.; O'Harte, F.P.M.; Yoon, T.W.; Swanston-Flatt, S.K. \& Flatt, P.R. (1996). Characterization of a novel glucose responsive insulin-secreting cell line, BRIN-BD11, produced by electrofusion, Diabetes, Vol. 45, pp. 1132-140.

Mosihuzzaman, M.; Nahar, N.; Ali, L.; Rokeya, B.; Azad Khan, A.K.; Nur-e-Alam, M.; \& Nandi, R.P. (1994). Hypoglycimic effects of three plants from Eastern Himalayan belt. Diab Res , Vol. 26, pp. 127-138.

Murshed, S.; Rokeya, B.; Nahar, N.; Azad Khan, A.K.; Mosihuzzaman, M.; Banerjee, A.; Maiti, S.; \& Ali, L. (2005). Hypoglycemic and Hypolipidemic Effect of Hemidesmus indicus Root on Diabetic Model Rats. Diab Res, Vol. 39, pp. 15-23.

Nagarajan, S.; Jain, H.C.\& Aulakh, G.S. (1982). Indigenous plants used in the control of diabetes. In: Cultivation and Utilization of Medicinal Plants (CK Atal, BM Kapur 
eds), pp. 584-604. Regional Research Laboratory, Council of Scientific and Industrial Research, Jammu-tawi, India.

Nahar, N.; Rokeya, B.; Ali, L.; Hassan, Z.; Nur-e-Alam, M.; Chowdhury, N.S.; Azad Khan, A.K. \& Mosihuzzaman, M. (2000). Effects of three medicinal plants on blood glucose levels of nondiabetic and diabetic model rats. Diab Res, Vol. 35, pp. 41-49.

Nahar, N.; Rokeya, B.; Ali, L.; Hassan, Z.; Nur-E-Alam, M.; Chowdhury, N.S.; Azad Khan, A.K. \& Mosihuzzamaan, M. (2000). Effects of three medicinal plants on blood glucose levels of nondiabetic and diabetic model rats. Diabetes Research, Vol. 35, pp.041-049.

Rao, P.G. \& Kodandaramaiah, J. (1982). Association of Chlorophyll content, phyllotaxy, photosynthesis and B group vitamins in some $\mathrm{C}_{3}$ and $\mathrm{C}_{4}$ plants. Proc. Indian Acad. Sci. (Plant Sci.), Vol. 91, No 6, pp. 495-500.

Rokeya, B.; Hannan, J.M.A., Rahman, M.H.; Nurun Nabi, A.H.M.; Ali, L.; Mosihuzzaman, M. \& Nahar, N. (2000). Chronic effect of cold aqueous extract of Allium sativum on glycemic and lipidemic status and platelet aggregation in Type 2 diabetic model rats. Diab Res Clin Pract, Vol. 50, No. 1, pp. S393.

Rokeya, B.; Mosihuzzaman, M.; Nahar, N.; Azad Khan, A.K.\& Ali, L. (2005). Hypoglycemic effect of PE071 seeds in type 2 diabetic Long-Evens rats. Diabetologia, Suppl 1 Vol. 761, pp. A276.

Rokeya, B.; Nahar, N.; Ali, L.; Hassan, Z.; Nur-e-Alam, M.; Chowdhury, N.S.; Azad Khan, A.K. \& Mosihuzzaman, M. (1999). Effects of five medicinal plants on blood glucose levels in nondiabetic and diabetic model rats. Diab Res, Vol. 34, pp. 219-228.

Rokeya, B.; Rahman, M.M.; Hannan, J.M.A.; Akter, M.; Lamin, M.; Azad khan, A.K. (2006). Insulin secretory effect of plant extracts PE080 and PE081 in perfused pancreas and BRIN-BD cells. Diabetologia, Vol. 49, suppl 1, pp. 0858.

Simmond, M.S.J \& Howes, M.J.R. (2006). Edited by A Soumayanath A. Traditional Medicine for modern times: Antidiabetic plants, Taylor \& Francis group, UK.

Singh, K.L.; Rao, J.; Srivastava, V. \& Tandon, J.S.; Arborside, D. (1995). A Minor Iridoid Glucoside From Nyctanthes arbor-tristis. Journal of Natural Products, Vol. 58, No. 10, pp.1562-1564.

Singh, R.B. \& Jindal, V.K. (1985). Polysaccharide from Nyctanthes arbor-tristis Linn. Seedsisolation, Purification and Preliminary Analysis of polysaccharide. Journal of the Indian Chemical Society August, Vol. 62, No. 7, pp. 627-628.

Singh, S.; Gupta, S.K.; Sabir, G.; Gupta, M.K. \& Seth, P.K. (2009). A database for anti-diabetic plants with clinical/ experimental trials. Bioinformation. Vol 4, No. 6, pp. 263-268 () 2009 Biomedical Informatics 263.

Sokeng, S.D.; Rokeya, B.; Hannan, J.M.A.; Junaida, K.; Zitech, P.; Ali, L.; Ngounou, G.; Lontsi, D.\& Kamtchouing (2007). Inhibitory effect of Ipomoea aquatica extracts on glucose absorption using a perfused rat intestinal preparation. Fitoterapia; 78: 526529.

Sokeng, S.D.; Rokeya, B.; Mostafa, M.; Nahar, N.; Mosihuzzaman, M. Ali, L \& Kamtchouing, P. (2005). Antihyperglycemic effect of Bridelia ndellensis ethanol extract and fractions in streptozotocin induced diabetic rats. Afr J Trad CAM, Vol. 2, pp. 94-102.

Srinivasa, R.M. (2007). Medicinal plant species with potential anti diabeties Properties. J Sci Food Agric, Vol. 87, pp. 743-750. 
Srivastava, V.; Rathore, A.; Ali, S.M. \& Tandon, J.S. (1990). New Benzoic esters of loganin and $6 \beta$-Hydroxyloganin from Nyctanthes arbortristis. Journal of Natural Products. Vol. 53, No. 2, pp. 303-308.

Stamler, J.; Vaccaro, O.; Neaton, J.D. et al. (1993). Diabetes, other risk factors and 12-year cardiovascular mortality for men screened in the Multiple Risk Factor Intervention Trial. Diabetes Care, Vol. 16, pp. 434-44.

Subbulakshmi, G. \& Naik, M. (2001). Indeginous food in the treatment of diabetes mellitus. Bombay Hosp Res J, Vol. 43, pp.548-561.

Tandon, J.S.; Srivastava, V. \& Guru, P.Y. (1991). Iridoids: A new class of leishmanicidal agents from Nyctanthes arbortristis. Journal of Natural Products. Vol. 54, pp. 11021104.

Tuomilehto, J.; Lindstrom, J.; Eriksson, J.G.; Valle, T.T.; Hamalainen, H.; Ilanne-Parikka, P.; Keinanen-Kiukaanniemi, S.; Laakso, M.; Louheranta, A.; Rastas, M.; Salminen, V.; \& Uusitupa, M. (2001). Prevention of type 2 diabetes mellitus by changes in lifestyle among subjects with impaired glucose tolerance. N. Engl. J. Med, Vol. 344, pp. 13431350. [PubMed]

World Health Organization (WHO), (2006). Diabetes Programme, Department of Chronic diseases and Health Promotion; Facts and Figures sheet-Diabetes, Geneva, Switzerland. 


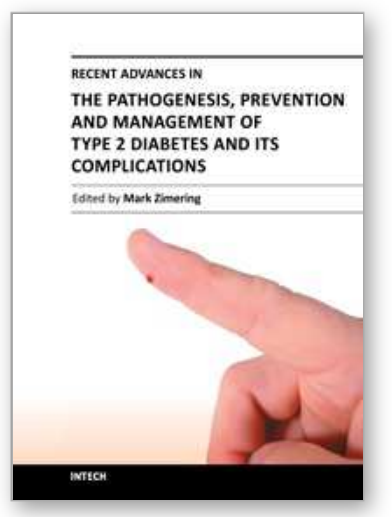

\author{
Recent Advances in the Pathogenesis, Prevention and \\ Management of Type 2 Diabetes and its Complications \\ Edited by Prof. Mark Zimering
}

ISBN 978-953-307-597-6

Hard cover, 442 pages

Publisher InTech

Published online 29, August, 2011

Published in print edition August, 2011

Type 2 diabetes â€œmellitusâ€ affects nearly 120 million persons worldwide- and according to the World Health Organization this number is expected to double by the year 2030. Owing to a rapidly increasing disease prevalence, the medical, social and economic burdens associated with the microvascular and macrovascular complications of type 2 diabetes are likely to increase dramatically in the coming decades. In this volume, leading contributors to the field review the pathogenesis, treatment and management of type 2 diabetes and its complications. They provide invaluable insight and share their discoveries about potentially important new techniques for the diagnosis, treatment and prevention of diabetic complications.

\title{
How to reference
}

In order to correctly reference this scholarly work, feel free to copy and paste the following:

Rokeya Begum, Mosihuzzaman M, Azad Khan AK, Nilufar Nahar and Ali Liaquat (2011). Emerging Challenge of Type 2 Diabetes: Prospects of Medicinal Plants, Recent Advances in the Pathogenesis, Prevention and Management of Type 2 Diabetes and its Complications, Prof. Mark Zimering (Ed.), ISBN: 978-953-307-597-6, InTech, Available from: http://www.intechopen.com/books/recent-advances-in-the-pathogenesis-preventionand-management-of-type-2-diabetes-and-its-complications/emerging-challenge-of-type-2-diabetes-prospectsof-medicinal-plants

\section{INTECH}

open science | open minds

\author{
InTech Europe \\ University Campus STeP Ri \\ Slavka Krautzeka 83/A \\ 51000 Rijeka, Croatia \\ Phone: +385 (51) 770447 \\ Fax: +385 (51) 686166 \\ www.intechopen.com
}

\author{
InTech China \\ Unit 405, Office Block, Hotel Equatorial Shanghai \\ No.65, Yan An Road (West), Shanghai, 200040, China \\ 中国上海市延安西路65号上海国际贵都大饭店办公楼 405 单元 \\ Phone: +86-21-62489820 \\ Fax: +86-21-62489821
}


(C) 2011 The Author(s). Licensee IntechOpen. This chapter is distributed under the terms of the Creative Commons Attribution-NonCommercialShareAlike-3.0 License, which permits use, distribution and reproduction for non-commercial purposes, provided the original is properly cited and derivative works building on this content are distributed under the same license. 